\title{
STUDY OF THE MARKET OF CONFECTIONARY PRODUCTS IN UKRAINE
}

\author{
Olena Bochko1, Yevhen Krykavskyy2 , Ignacy Petetskyi ${ }^{3}$, Kestutis Liekis ${ }^{4}$, Birute \\ Aleksandraviciute ${ }^{5}$
}

Received: 2021-03-11

Accepted: 2021-04-16

DOI: http://doi.org/10.46489/gpj.2021-1-1-7

\begin{abstract}
The article presents the investigation of the market of confectionery products in Ukraine. We identified the reasons mentioned by consumers while choosing domestic producers, namely price availability, high quality, the trend of domestic goods consumption, a wide range of products. We analysed marketing positions of the primary producers of confectionary products, i.e. SE "CC "ROSHEN", PJSC "Confectionary factory "AVK", PJSC PC "Konti", LCF "Svitoch" (Nestle), PJSC "Mondelis Ukraine", PJSC "KhBF", ZhCF "Zhytomyrski lasoshchi", PJSC "Poltavakondyter". Based on the conducted marketing research, we found that $45 \%$ of consumers buy confectionary products $2-3$ times a week and $40 \%-4$ times and more. Furthermore, while purchasing the confectionary products, the respondents mostly consider the price $-35 \%$ of the interviewees, brand and actions - $25 \%$. Among the examined companies, consumers mostly prefer Roshen $-75 \%$. Among the range of products, the preferable are sweets and chocolate $-30 \%$, cakes $-20 \%$, marshmallows and marmalade, and sweets in boxes - 15\% each. During the COVID-19 pandemic, the purchasing capacity in the branch of confectionery products has changed, whereas the consumers' spending for confectionary products has not diminished. According to the results of the conducted research, we confirmed that $40 \%$ of consumers have not changed their spending, 35\% - have reduced their spending for confectionary products, whereas $25 \%$ - have significantly cut down their spending.
\end{abstract}

Keywords: market, confectionary products, producers, competitors, consumers

\footnotetext{
1 Olena Bochko, DSc, Professor, Department of marketing and logistic, Lviv Polytechnic National University Lviv 79013, StepanaBandery str., 12, Ukraine, e-mail: bochkoolena@ukr.net, ORCID: https://orcid.org/0000-00033422-4654

${ }^{2}$ Yevhen Krykavskyy, DSc, Professor, Department of marketing and logistic, Lviv Polytechnic National University Lviv 79013, StepanaBandery str., 12, Ukraine, ORCID: https://orcid.org/0000-0002-1847-586X

3 Ignacy Petetskyi, PhD, Chairman of the Board of "PETECKI" Company, 11/13, Rudzka, Lodz, Poland, email: sekretariat.chrapczew@petecki.eu, ORCID: https://orcid.org/0000-0002-6048-8437

${ }^{4}$ Kestutis Liekis, PhD, KLQ Ltd, United Kingdom, e-mail: k.liekis@outlook.com, ORCID: https://orcid.org/00000002-6723-2223

5 Birute Aleksandraviciute, PhD, Mykolas Romeris University, Lithuania, e-mail: birute.aleksandraviciute@gmail.com, ORCID: https://orcid.org/0000-0003-2819-1315
} 


\section{ВСТУП}

Кондитерська галузь $є$ однією 3 небагатьох успішних і привабливих галузей української економіки. В Україні ринок кондитерських виробів сформувався досить давно. В умовах пандеміï COVID 19 і глибокої економічної кризи, спричиненої здебільшого політичними чинниками, аналіз основних тенденцій, факторів впливу й особливостей роботи кондитерської галузі економіки $\epsilon$ особливо актуальним, оскільки саме ця галузі народного господарства забезпечують виживання країни. Даний сегмент характеризується високим рівнем конкуренції й великою кількістю кондитерських підприємств, що зумовлює наявність широкого асортименту продукції. Вітчизняними науковцями висвітлено багато теоретико-прикладних проблем, запропоновані напрями їх усунення, проаналізовано чинники впливу на розвиток ринку кондитерських виробів, зокрема Тюха I. В., Кравчук Н. В. вивчали тенденції розвитку міжнародного кондитерського ринку (Tiukha, I.V., Kravchuk, N.V. , 2012); Шашина М. В. розкривала можливі шляхи удосконалення ресурсного потенціалу кондитерської галузі; Кроніковський Д. О. аналізував економічні фактори впливу на ринок кондитерських виробів (Kornikovskyi, D. O., 2014).

\begin{tabular}{ccc} 
У & \multicolumn{2}{c}{ структурі } \\
кондобництва
\end{tabular} натуральному вираженні більше половини $(55,3 \%)$ займають різні борошняні вироби. Шоколад і продукти з вмістом какао разом складають 23,6\%. Значна частка продукції на кондитерському ринку - українського виробництва (близько 95\%), проте імпорт у даному сегменті показує активне зростання. Це пов'язано зі зростанням інтересу українських споживачів до зарубіжних солодощів, які сприймаються як більш якісні.
Конкуренція на внутрішньому ринку солодощів досить велика. У галузі налічується близько 750 підприємств. Великим виробникам з часткою ринку в $10 \%$ доводиться боротися за увагу покупця 3 невеликими місцевими підприємствами і торговими мережами 3 власними пекарнями (Sokolov, O., 2018).

Останні декілька років ринок кондитерських виробів в Україні активно розвивається, розширюється асортимент, використовуються інноваційні технології. Українці стали витрачати на їжу майже вдвічі більше, ніж п'ять років тому - витрати на продовольство виросли на 75\%. При цьому $12 \%$ всього бюджету віддають за солодощі. Про це свідчить той факт, що українські виробники солодощів традиційно входять до світових топрейтингів кондитерів. У 2020 році за результатами світового рейтингу спеціалізованого видання Candy Industry, корпорація Roshen посіла 29-те місце з обсягом чистих продажів у $\$ 800$ млн., 73 місце - Шоколадна фабрика "Тисячоліття" - \$205 млн; 89 місце Konti - \$147 млн. У лідерах рейтингу Кондитерська "Mars Wrigley" (1 місце) Ferrero Group (2-ге місце) i Nestle (6-те місце), які володіють вітчизняними брендами «Світоч» і «Корона» (Candy Industry, 2021).

Смакові переваги українців різняться за віковими категоріями молодь значною мірою споживає батончики i шоколадки, люди середнього віку та пенсіонери більше люблять борошняну продукцію. Водночас у всіх категорій споживачів активним попитом користуються цукерки і печиво на вагу (Pro consulting. Analityka rynkiv, finansovyi konsaltynh, 2018).

\section{РЕЗУЛЬТАТИ}

Для чіткішого розуміння структури галузі кондитерських виробів в Україні, слід розглянути основних виробників 
на ринку. Дві третини всього ринку і три чверті експорту контролюють: ДП "КК "РОШЕН", ПрАТ «Кондитерська фабрика «АВК», ПрАТ ВО «Конті», ЛКФ «Світоч» (Nestle), ПРАТ «Монделіс Україна», ПрАТ «ХБФ», ЖКФ «Житомирські ласощі», ПрАТ «Полтавакондитер». Загалом український споживач віддає перевагу товарам власного виробника, що пов'язано з кількома причинами:

- ціни на вітчизняні цукерки нижче, ніж на імпортні;

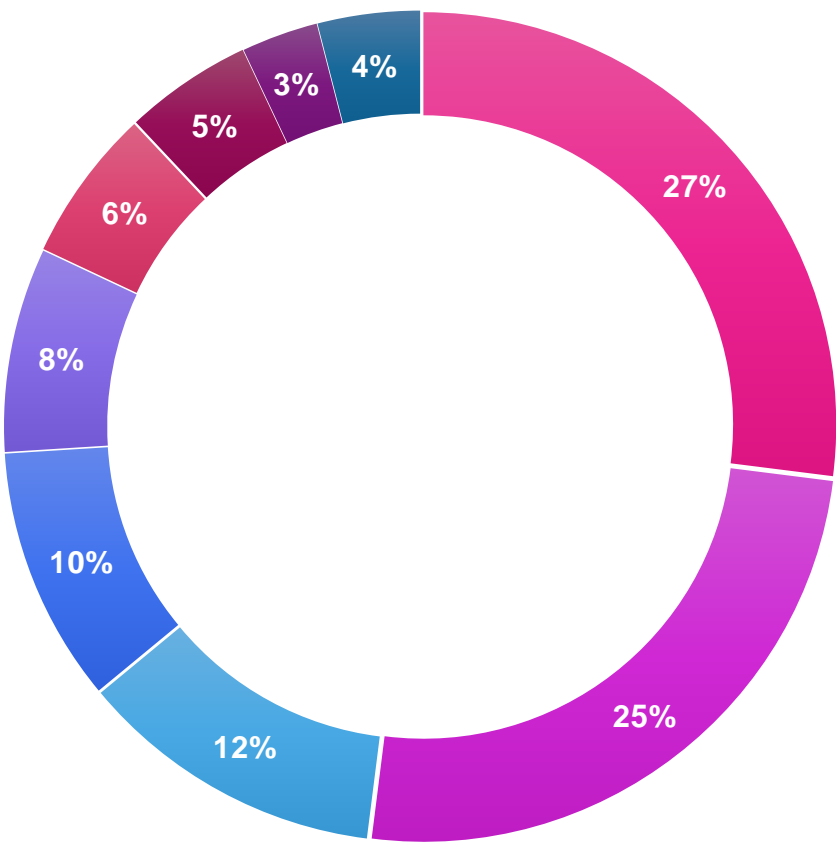

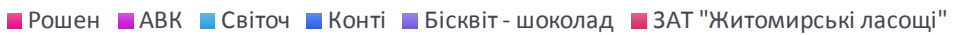

— ВАТ "Полтавкондітер"

КФ"Лагода" в інші

Рис.1 Ринок кондитерських виробів України

Ажерело: сформовано авторами за віАкритими даними

Розглянемо основних виробників ринку кондитерських виробів більш детально.

1. Корпорація «Roshen». Лідер українського ринку кондитерської продукції. Компанія існує з 1996 року. Продукцію можна купити в США, Канаді, OАЕ, Китаї, Японії, Алжирі, Ізраїлі, країнах ЄС, і СНД. Roshen стабільно входить в топ 100 кондитерських компаній світу. Кондитерська Корпорація ROSHEN у рейтингу Global Top-100 Candy Companies посідає 27-те місце. ROSHEN виробляє понад 320 найменувань високоякісних кондитерських виробів. В асортимент корпорації входять шоколадні та желейні цукерки, карамель, ірис, шоколадні плитки та батончики, печиво, вафлі, бісквітні рулети, тістечка та торти. На підприємствах корпорації ROSHEN працює система управління якістю, яка відповідає вимогам ISO 9001:2008, та система управління безпечністю харчових продуктів, яка відповідає вимогам стандарту ISO 22000:2005, що підтверджується наявністю у кожної з фабрик Корпорації сертифікатів відповідності (Korporatsiia «Roshen», 2021). Кондитерська 
корпорація «Роше́н» - один 3 найбільших виробників кондитерських виробів в Україні та Східній Європі, входить у тридцятку найбільших виробників кондитерських виробів світу. Головний офіс компанії розташовано у Києві. ROSHEN виробляє понад 320 найменувань високоякісних кондитерських виробів. В асортимент корпорації входять шоколадні та желейні цукерки, карамель, ірис, шоколадні плитки та батончики, печиво, вафлі, бісквітні рулети, тістечка та торти. Деякі з них не мають аналогів на ринку України. Загальний обсяг виробництва продукції сягає близько 300 тисяч тон на рік (Korporatsiia «Roshen», 2021).

2. Група «Конті». Заснована в 1997 році, і входить в трійку лідерів українського ринку кондитерських виробів. Сьогодні підприємство є одним 3 лідерів 3 виробництва кондитерської продукції в Україні. В місяць на фабриці може вироблятися до 2 тисяч тон продукції (Hrupa «Konti», 2021).

3. «АВК». Компанія працює з 1991 року, основні виробничі потужності знаходяться в Дніпропетровській області - це фабрика площею 14639 кв. м. Експортує в більш ніж 20 країн світу, серед яких Німеччина, Великобританія, Латвія, і Ізраїль. Виробництво компанії сертифіковано відповідно до міжнародної системи менеджменту якості ISO 9000, ISO 22000. У 2017 році високу якість нашої продукції підтверджено міжнародним стандартом IFS, що дає можливість продажів солодощів під брендом АВК в торгові мережі країн Європейського Союзу. Однією 3 найпопулярніших $\epsilon$ серія «Труфалье». Компанія також постраждала через проведення АТО, довелося призупинити роботу Донецької та Луганської фабрик. Ще одна фабрика знаходиться в Мукачево (Закарпатська область), на їі офіційному сайті шукають інвесторів, готових вкласти гроші або викупити фабрику (Kompaniia «AVK»., 2021).

4. Nestle Україна. На Українському ринку з 1994 року, хоча кондитерський напрям - не основна спеціалізація корпорації. В Україні з 1998 року володіє брендом «Світоч». Сьогодні компанія просуває на українському ринку продукцію торгових марок NESCAFÉ, Nesquik, Coffee-mate, Nuts, KitKat, Lion, Purina, Gerber, „Світоч”, „Торчин” та „Мівіна”, котрі користуються великою популярністю серед споживачів (Nestle Ukraina, 2021).

5.Кондитерская фабрика «Житомирські ласощі». Фабрику було засновано у 1944 році і сьогодні вона $\epsilon$ найстарішим із підприємств кондитерської галузі України. Компанія виробляє продукцію для діабетиків. Виробнича потужність підприємства 80 тисяч тонн продукції на рік. Підприємство Житомирські ласощі виробляє шоколадні, пралінові, помадні, вафельні та грильяжні цукерки, нугу, ірис, батончики, вафлі, різні види печива, а також, інші кондитерські вироби (Kondyterskaia fabryka «Zhytomyrski lasoshchi», 2021).

6. Корпорація "Бісквіт-Шоколад" (в склад входить ПрАТ «ХБФ»). Харківське підприємство, існує з 2001 року, включає в себе 2 фабрики. Експортує у Казахстан, Киргизстан, Грузію, Азербайджан, Молдову, Латвію, Литву, Монголію, США, Канаду, Ізраїль, Німеччину. На експорт йде близько $30 \%$ усієї виробленої продукції. Карамель, цукерки (глазуровані і неглазуровані), шоколад, зефір, ірис, мармелад - основна продукція фабрики. Корпорація "Бісквіт-Шоколад" була першою серед українських кондитерських компаній, хто взяв участь в міжнародній виставці ISM в 2000 році, де представила не тільки свою продукцію, але і Україну. Системи менеджменту якості та безпеки продуктів харчування на підприємствах корпорації відповідають сучасним міжнародним стандартам ISO 9001, ISO 
22000 та FSSC 22000. На підприємствах компанії зайнято понад 2,2 тис. осіб (PrAT «KhBF», 2021).

7. ПАТ «Полтавкондитер» (торгова марка Домінік). Кондитерська фабрика виробляє до 200 тонн продукції в день, експортує в Естонію і Грузію, як і інші країни сильно постраждала від російського ембарго на українські продукти. Виробничі потужності - 2 фабрики, обидві в Полтаві. Бренд «Домінік» випускає близько 50 видів цукерок. 3 іншого боку, в регіонах продукцію частіше можна знайти на ринках або маленьких магазинчиках.

8. Монделіс Україна. Український підрозділ швейцарського гіганта, до 2014 року називався «Крафт Фудз Україна», належить групі «Mondelēz InternationaL», найбільшого в світі виробника шоколаду, шоколадних цукерок i печива. В Україні працює Тростянецька фабрика, на якій виробляють шоколадки і мінішоколадки «Milka», «Alpen Gold» i «Корона». «Монделіс Україна» позиціонує себе як соціальновідповідальна компанія, яка реалізує низку соціальних та благодійних ініціатив (Mondelis Ukraina, 2021).

Загалом на українському ринку кондитерських виробів дуже висока конкуренція. Якість продукції тримається на високому рівні. Лідери українського ринку постійно потрапляють в «Тор 100 Candy Companies», головний критерій відбору для рейтингу - річні виручки з продажів. Відмітимо велику втрату ринків збуту в Криму, і на території проведення АТО, а також закриття російського ринку, i перешкоди 3 транзитом через територію Росії відбилися на стані кондитерської галузі. Roshen втратила в продажах, опустившись в світовому рейтингу на 8 позиції.

3 метою вивчення потреб споживачів та їх вподобання, конкурентів, вагомість торгової марки, вплив бренду на поведінку покупців, основні фактори, що впливають на вибір продукції ми провели маркетингове дослідження через GOOGLE FORMS щодо їх вподобань та систематизовано програмою SPSS. Згруповані відповіді наведено в табл. 1.

Таблиця 1

Базові дані проведеного АосліАження (частина)

\begin{tabular}{|c|c|c|c|c|c|c|c|c|c|c|c|c|}
\hline 1 & Познячкв чвсу & Скільки Вам років? & Ввша стать? & ? Як часто Ви купуете кон & + 4 в впл. & и Чи зменшились Вэші & : На що Ви н: & 4: Як часто Ви користуете & Tb eir Ceped H. & $4 n \mathrm{ks}$ & Що з зсортименту пр & $=4$ ४ $889 \%$ \\
\hline 2 & 09.05 .2021 & $18-25$ & Жіноия & $4 i$ бiльше разів на міся & a tak & Зменшились & Бренд/Biдо। & of 1-2 рязи на тихдень & 4 Рошен & так & Цукерки та шоколяд & Tak \\
\hline 3 & 09.05 .2021 & $18-25$ & Чоловічя & 2-3 рази ня місяць & Tak & Heamiнni & Lims & 1-2 рөзи на тикдень & 5 Рошен & так & Зефір тя мярмеляд & Tak \\
\hline 4 & 07.05 .2021 & Ao 18 & Чоловічя & $4 \mathrm{i}$ більше разів на місян & a tak & Незмінні & Брена/Відол & pr 6iльше 2 pasis & 4 Рошен & нi & Kexcn & так \\
\hline 5 & 09.05 .2021 & $18-25$ & Жіноия & 2-3 рөзи на місячь & Hi & Зменшились & Доступність & b Ginьwe 2 pasis & 4 Рошен & так & Цукерки та шоколяд & Taк \\
\hline 6 & 07.05 .2021 & $26-35$ & Чоловіuя & 4 i бiльше разів нa micaı & 1 tak & Зменшились & Axuाi & 1-2 рази на тикдень & 5 Рошен & так & Торти & Tak \\
\hline 7 & 09.05 .2021 & $36-50$ & Жіноия & 4 i Giльше раsis на місяь & 1 так & Незмінні & ціня & Ginьше 2 pasis & 3 Ceitou & так & Цукерки в коробках & так \\
\hline 8 & 08.05 .2021 & $18-25$ & Чоловічя & $4 i$ більше разів на місан & & Вягомо зменшились & Lіна & не користуюсы дяними т & 5 Рошен & так & Зефір та мярмеляд & нi \\
\hline 9 & 09.05 .2021 & $50+$ & Жіноия & 2-3 рази на місяць & так & Вягомо зменшились & Axцाi & не користуюоь дяними т & 4 Рошен & так & Kexcn & так \\
\hline 10 & 09.05 .2021 & $18-25$ & पоловіus & 4 i Giльше разів на міся н & & Зменшилиоь & Бренд/Відо & ") Ginьше 2 pasis & 4 ABK & так & Цукерки та шоколяд & так \\
\hline 11 & 09.05 .2021 & $26-35$ & Жіноия & 2-3 рэзи на місяцьь & Tak & Bsгомо зменшились & Lims & 1-2 рази ня тихаень & 4 Рошен & Tak & Цукерки та шоколяд & нi \\
\hline 12 & 09.05 .2021 & A० 18 & Чоловіus & 1 раз на міслцьв & нi & Незмінні & Lima & 1-2 рази на тикаень & 4 Ceitou & Tak & Торти & Tak \\
\hline 13 & 09.05 .2021 & $36-50$ & Чonoвius & 4 i більше раsis на міся & & Вягомо зменшились & Брена/Відо & ") Giльше 2 pasis & 5 ABK & Tak & Kexcn & Tak \\
\hline 14 & 08.05 .2021 & $18-25$ & Чоловічя & 2-3 рязи на місаць & $\operatorname{Tak}$ & Зменшились & Axuाi & не користуюсь дяними т & 4 Рошен & так & Цукерки та шоколяд & так \\
\hline 15 & 09.05 .2021 & $50+$ & Жіноия & 2-3 рөзи на місяць & Tak & Вягомо зменшились & Lima & не користуюсь дяними : & 3 Рошен & так & Торти & Tak \\
\hline 16 & 05.05 .2021 & $26-35$ & Чоловіus & 1 раз на міслць & нi & Незмінні & Axuाi & Ginьwe 2 pasie & 5 Рошен & нi & Kexcn & нi \\
\hline 17 & 09.05 .2021 & $18-25$ & Чоловіus & 2-3 рази на місяцьь & нi & Незмінні & Брена/Відо, & b) Giльше 2 pasis & 5 Cairou & Tak & Цукерки та шоколяд & нi \\
\hline 18 & 09.05 .2021 & A0 18 & Жіноия & 2-3 рязи на місяцьь & так & Незмінні & Доступність: & - 1-2 рази на тихдень & 5 Рошен & Hi & Цукерки в коробках & Tak \\
\hline 19 & 09.05 .2021 & $36-50$ & Жіноия & 4 i більше разів на місяа н & & Зменшились & Axuाi & Giльше 2 pasis & 4 Рошен & Hi & Торти & так \\
\hline 20 & 06.05 .2021 & $26-35$ & Жіноия & влясна вianosiab & нi & Незмінні & Доступність & b не користуюсь дяними $t$ & 3 Рошен & Hi & Зефір та мярмеляд & так \\
\hline 21 & 09.05 .2021 & $18-25$ & Чоловічя & 2-3 рөзи на місяць & так & Зменшились & Ціна & 1-2 рази на тихдень & 4 Рошен & Tak & Цукерки в коробках & так \\
\hline
\end{tabular}

Ажерело: сформовано авторами

За результатами проведеного дослідження встановлено, що 55\% опитаних респондентів чоловіки і тільки $45 \%$ - жінки, $40 \%$ опитаних вікової категорії - 18-25 років, 20\% - 26-
35 років, $10 \%$ - становлять респонденти старше 50 років. Серед опитаних 45\% купують кондитерські вироби 2-3 рази на тиждень та $40 \% 4$ і більше разів на тиждень (рис. 2). 


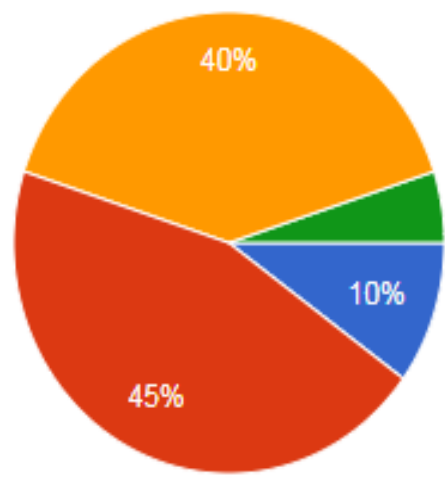

1 раз на місяць

2-3 рази на місяць

4 і більше разів на місяцьь

власна відповідь

Рис. 2 Результати опитування респондентів щодо частоти купівлі кондитерських виробів Ажерело: сформовано авторами

Встановлено, що при купівдлі кондитерських виробів найбільше респонденти звертають увагу на ціну -
$35 \%$ опитаних, бренд та акції -25\% (рис. 3).
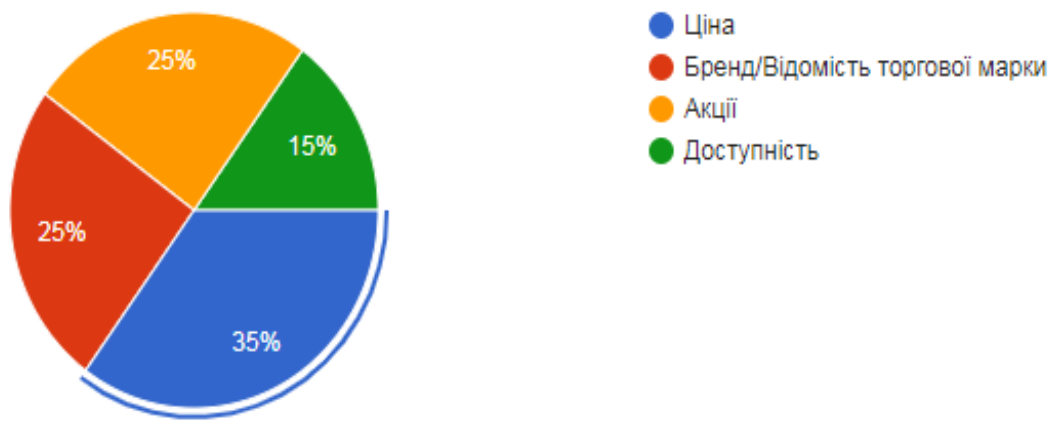

Рис. 3 Результати опитування респондентів щодо акцентів при купівАі кондитерських виробів Ажерело: сформовано авторами

Нами досліджувалось також чи вплинув COVID 19 на процес купівлі кондитерськихх виробів та встановлено, що вплинув, але тіки частоково, оскільки 40\% не змінували свої витрати на кондитерські вироби, у 35\%

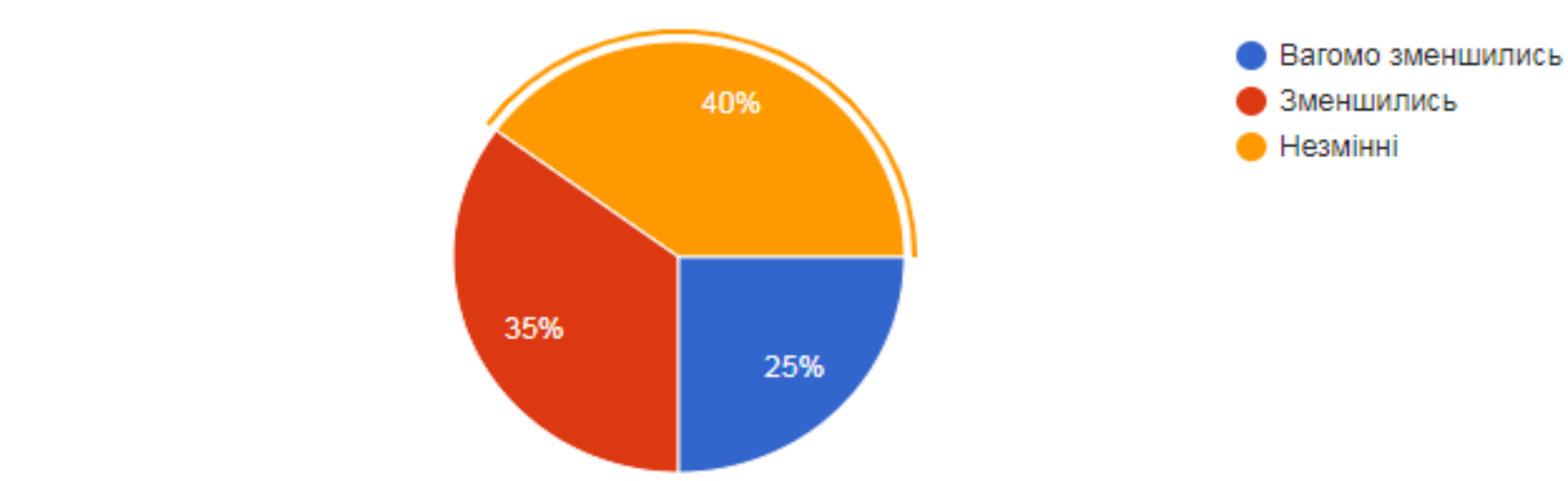

опитаних зменшились і тільки у 25\% вагомо зменшились (рис. 4). Як бачимо у більшої кількості респондентів зростання витрат на кондитерські вироби не відбулося.

Рис. 4 Результати опитування респондентів щодо зміни витрат на кондитерські вироби Ажерело: сформовано авторами

Доцільно відмітити, що в період пандемії особлива увага споживачів в межах ринку кондитерських виробів була націлена на доставку продуктів. 
Зокрема серед респондентів 40\% здійснювали онлайн замовлення більше ніж 2 рази на тиждень, 35\% - 1-2 рази на тиждень та $25 \%$ завсім не користувалися онлайн послугами. Переважно споживачі вважають за необхідне створити онлайн магазини для кондитерських компаній (рис. 5).

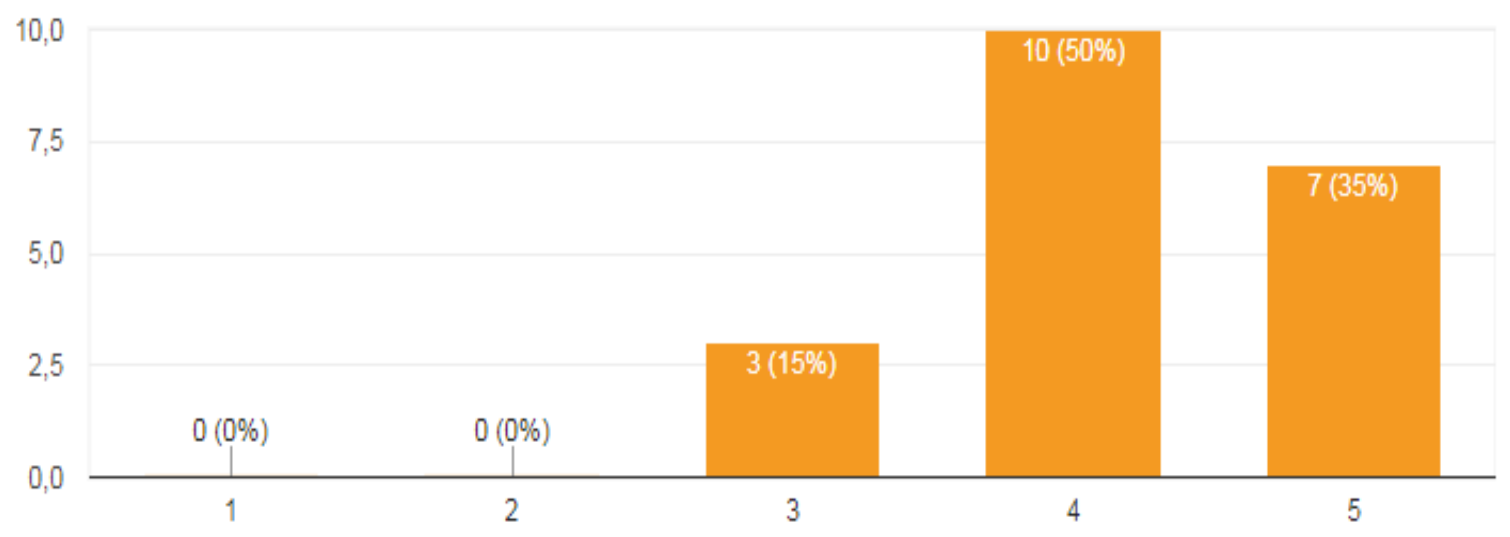

Рис. 5. Рівень важливості створення онлайн магазинів Аля кондитерських компаній Ажерело: сформовано авторами

Серед досліджуваних компаній на ринку кондитерських послуг споживачі найбільшу перевагу торговій марці «Рошен» - 75\%. Із всього асортименту споживачі найбільшу перевагу віддають цукеркам та шоколаду - 30\%, торти та кекси - 20\%, а зефір та мармелад, а також цукерки в коробках- по 15\% (рис. 6).

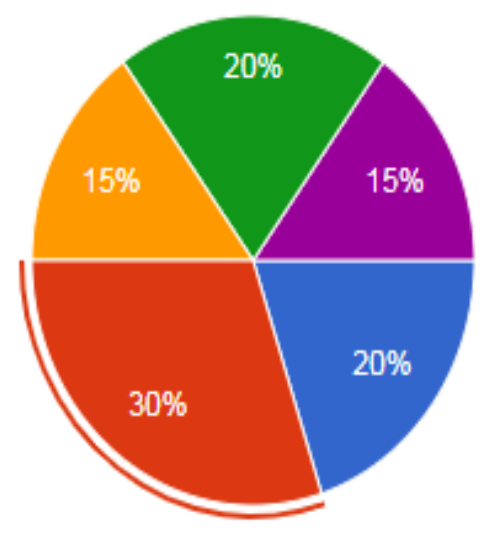

Торти

- Цукерки та шоколад

Зесір та мармелад

Кекси

Ццккерки в коробках

Рис. 6. Результати дослідження щодо вподобань споживачами продукції TM «Рошен»

Ажерело: сформовано авторами

Відмітимо, що 3/4 всіх респондентів використовують сайт для отримання

\section{висновки}

За результатами проведеного дослідження можемо стверджувати: інформації про продукцію, більшість шукають акційні товари.

1. Більша частина населення України - майже 85\% споживає солодощі. 
2. Під час COVID-19 купівельна спроможність в галузі кондитерських виробів дещо змінилася, проте витрати споживачів на солодощі не дуже зменшилися. $40 \%$ споживачів зовсім не змінили свої витрати, 35\% зменшили свої витрати на кондитерські вироби, натомість $25 \%$ вагомо зменшили свої витрати.

3. При виборі солодощів, споживачі опираються на відношення ціна-брендакції.

4. Дослідження показало, що $25 \%$ споживачів зовсім не користуються

\section{References}

Candy Industry (2021). Global Top 100 Candy Companies. Retrieved February 03, 2021,

from https://www.candyindustry.com/2021/gl obal-top-100-candy-companies

Hrupa «Konti». Retrieved January 15, 2021, from https://konti.ua/ourproduction 15 ,

Kompaniia «AVK». Retrieved January from https://www.avk.ua/ua/uk/quality

Kondyterskaia fabryka «Zhytomyrski lasoshchi». Retrieved February 15, 2021, from https://www.avk.ua/ua/uk/quality

Kornikovskyi, D. O. (2014). Analiz ekonomichnykh faktoriv vplyvu na kondytersku promyslovist Ukrainy. Ekonomika kharchovoi promyslovosti. 24. c. 47-49.

http://journals.uran.ua/fie/article/view/3 6086

Korporatsiia «Roshen». Retrieved January 12, 2021, from https://roshen.com/?fbclid=iwar1hls1bcu o9tbjk_gbj4ojcjdy6ifcwlrnsg5za-

tcbs4_atby22qlkbcq

Kryskova, L. (2019) Rynok kondyterskoho vyrobnytstva $\mathrm{v}$ Ukraini Materialy naukovoi konferentsii Ternopilskoho natsionalnoho tekhnichnoho universytetuimeni Ivana Puliuia, Ternopil. http://elartu.tntu.edu.ua/bitstream/li онлайн послугами, $\epsilon$ такі що зрідка користуються послугами доставки це приблизно 1-2 рази в тиждень та більшість ті, які хто більше 2-ох разів на тиждень користується такими послугами.

5. У рейтингу найпопулярніших компаній за версією споживачів: перше місце посідає торгова марка «Рошен» 75\%, друге «Світоч» - 15\%, третє - «АВК» - 10\%. Щодо продукції, яким надають перевагу: 30\% - цукерки та шоколад, 20\% - кекси, 20\% - торти, 15\% - зефір та мармелад, 15\% - цукерки в коробках.

b/28194/2/XXI_NK_2019_Kryskova_LMarket_of_confectionary_141-142.pdf

Mondelis Ukraina. Retrieved January 15 , 2021,

from https://ua.mondelezinternational.com/ab out-us/our-team

Mykolska, N.V. (2017) Eksport kondyterskykh vyrobiv. Ministerstvo ekonomiky Ukrainy. http://www.me.gov.ua/News/Detail?lang= uk-UA\&id=84dc93af-d94c-472c-8880-

82ab171b4440\&title $=$

EksportKonditerskikhVirobivZa7-

Misiatsiv2017-ZrisNa16-

NataliiaMikolska\&isSpecial=true

Nestle Ukraina. Retrieved January 15, 2021,

from https://www.nestle.ua/aboutus/nestleinu kraine

PrAT «KhBF». Retrieved January 09, 2021, from https://biscuit.com.ua/

Pro consulting. Analityka rynkiv, finansovyi konsaltynh. Analiz rynku shokoladnykh kondyterskykh vyrobiv Ukrainy. 2018. Retrieved February 13, 2021, from https://proconsulting.ua/ua/issledovanie-

rynka/analiz-rynka shokoladnyhkonditerskih-izdelij-ukrainy2018-god

Sokolov, O. (2018) Ekonomika solodoshchiv: shcho i yak spozhyvaiut ukraintsi. Minde. https://mind.ua/openmind/20187556- 
ekonomika-solodoshchiv-shcho-i-yakspozhivayut-ukrayinci

The specialized site of the Candy Industry world confectionery market: website. Retrieved March 03, 2021, from http://www.candyindustry.com
Tiukha, I.V., Kravchuk, N.V. (2012). Suchasni tendentsii rozvytku svitovoho rynku kondyterskykh vyrobiv. Tsukor Ukrainy. Ekonomika i upravlinnia, 8(80). http://nbuv.gov.ua/UJRN/Cu_2012_8 $\underline{7}$ 